\title{
UK set to allow research on embryonic stem cells. ..
}

On August 16, Liam Donaldson, the UK Chief Medical Officer and leader of the Expert Advisory Group on Therapeutic Cloning, published a report recommending extending current legislation governing embyro research to allow the use of nuclear transfer (cloning) technology to create embryos specifically for research on embryonic stem cells (ESC). The government has accepted the recommendations and, if they are endorsed by parliament, the UK will be the first country in Europe to allow research on therapeutic cloning.

The report, Stem Cells: Medical Progress with Responsibility, unequivocally states that the transfer of an embryo created by cell nuclear replacement into the uterus of a woman (so called 'reproductive cloning) should remain a criminal offence, and transfering the nucleus from an adult cell into the cell of an embryo will remain prohibited. However, it states that, "Research using embryos (whether created by in vitro fertlization or cell nuclear replacement) to increase understanding about human disease and disorders and their cell-based treatments should be permitted, subject to the controls in the Human Fertlisation and Embryology Act 1990."

That act, which was established in 1990 and is overseen by the Human Fertlisation and Embryology Authority (HFEA), currently permits research on human embryos up to 14 days old but restricts it to specific reproductive purpose-infertility, congenital disease, gene or chromosomal abnormalities, miscarriage, or contraception. However, the use of nuclear transfer-which is needed in any therapeutic cloning program-is currently a grey issue: Although nuclear transfer of genetic material from an adult cell into an enucleated egg is currently not prohibited, neither is it specifically allowed. Alastair Kent, director of the patients organization Genetic Interest, says this is because, 10 years ago, "Using stem cells for addressing diseases that occur in adults patients was not thought possible."

A change in the law will clarify the grey area and allow researchers to clone embryos specifically for the purpose of harvesting ESCs for therapeutic research. Until now, scientists have had to derive ESCs from 'spare' embryos from in vitro fertilisation (IVF) projects-embryos that have been in short supply and sometimes of questionable quali-

Sabine Louët is a freelance writer working in London. ty. Austin Smith, director of the Centre for Genome Research at the University of Edinburgh, has been conducting work on stem cells to identify viable embryos for IVF, and says use of nuclear transfer will tremendously improve the quality of embryos.

\section{It will be a good test of the UK government support for biotech in general.}

Altering the HFEA act, which-unlike the regulations in the US-governs both public and private activity, will also encourage development of the UK's regenerative medicine industry, says Simon Best, CEO of the women's health startup Ardana Bioscience (Edinburgh, UK) and Chair of the Biotechnology Industry Organization (Washington, DC) international ethics committee. Until now, regenerative medicine research has been limited in the UK to nonreproductive work on adult and fetal stem cells, which are considered to have less plasticity than those that are embryonic. Donaldson's recommendations "relate to a particular area of medicine in which the UK has a lot to contribute", says Best, "If ratified [by parliament], it will keep the UK science at the forefront of a very important area of medicine."

However, a revision in the law would apply to basic research only; treating patients with ESC-based therapies would still be prohibited. "The need for legislation to permit the use of embryo-derived cells in treatments developed from this new research should be kept under review," states the report. Best says this will allow researchers to assess whether therapeutic cloning is as exciting as they believe while at the same time allowing continued public debate. "It leaves a lot of power to HFEA and is an appropriate extension of the law," he says.

The parliamentary test of the legislation will take place in the form of a 'free vote'whereby MPs can vote according to their conscience rather than to their party's political line-before the end of this year. Some think the hearing is important not only for the therapeutic cloning community but also for biotechnology in general. As Best points out, "it [will be] a good test of the UK government support for biotech in general which will determine whether biotech is an important part of the UK economy 20 or 30 years down the road."

Sabine Louët 